\title{
İç Mimarlık Bölümlerindeki Temel Tasarım Eğitimine Yönelik Öğrenci Tutumu
}

\author{
İpek Yildırım ${ }^{1 *}$ \\ ${ }^{1 *}$ Nuh Naci Yazgan University, Faculty of Fine Arts and Design, Departmant of Interior Architecture and Environment Design, Kayseri, Turkey, (ORCID: 0000-0001- \\ 8782-9943), iyildirim@nny.edu.tr \\ (Uluslararası Araştırma-Geliştirme ve Tasarım Konferansı - 15-18 Aralık 2021)
}

(DOI: 10.31590/ejosat.1039952)

\begin{abstract}
ATIF/REFERENCE: Yıldırım, İ. (2021). İç Mimarlık Bölümlerindeki Temel Tasarım Eğitimine Yönelik Öğrenci Tutumu. Avrupa
\end{abstract} Bilim ve Teknoloji Dergisi, (32), 353-361.

\section{$\ddot{O} z$}

Öğrenme ve deneyimle birlikte tutumun değişebileceği temelinden yola çıkan çalışma, tasarım ile ilgili alanlarda ilk yıl müfredatı kapsamında, öğrencilere temel tasarlama yeti ve becerilerini kazandırmak amacıyla verilen temel tasarım eğitimine yönelik öğrenci tutumunu ele almaktadır. Bu ele alış ile ders başlangıcında ve sonunda yani öğrenme sonucu öğrenci tutumlarında meydana gelebilecek olası farklılıkları belirlemek amaçlanmıştır. Bu amaç doğrultusunda nitel yöntemle oluşturulan çalışma ile Nuh Naci Yazgan Üniversitesi İç Mimarlık ve Çevre Tasarımı Bölümü’nde ilk yıl eğitimi kapsamında verilen temel tasarım eğitimi dersinin 2019-2020 Eğitim Öğretim Yılı Güz Yarıyılında derse yönelik tutumu tespit etmek amacıyla öğrencilere, iki aşamalı anket çalışması uygulanmıştır. Çalışmanın ilk aşaması yarıyılın üçüncü haftasında 51 öğrenciye, ikinci aşaması ise 14 . hafta 45 öğrenciye uygulanmış, anket sonucu elde edilen veriler SPSS programıyla analiz edilerek bulgulara ulaşılmıştır. Çalışmada ulaşılan sonuçlar doğrultusunda, öğrencilerin temel tasarım eğitimine yönelik genel olarak olumlu tutumlara sahip oldukları, ikinci aşamada herhangi anlamlı bir tutum değişikliği olmadığ s sadece erkek öğrencilerin zamanla dersin ödevlerine yönelik tutumlarının olumsuz yönde değiştiği görülmektedir. Öğrencilerin dersle yeni tanışmış olmalarına rağmen derse yönelik olumlu tutumlar beslemeleri ve önyargılı olmamaları olumlu olmakla birlikte, ikinci durumdaki olumsuzluk göz önünde bulundurularak dersin yöntemi ya da çalışmalarının günümüz öğrenci profili ve beklentilerinin dikkate alınarak güncellenmesi gerekliliklerini ortaya koymaktadır.

\section{Student Attitude Towards Basic Design Education In Interior Design Departments}

\begin{abstract}
Based on the fundamental that attitude can change with learning and experience, the study deals with student attitudes towards basic design education, which is given to students in the first year curriculum in design-related fields. Thus, it is aimed to identify possible differences in student attitudes at the beginning and end of the lesson. In order to determine the attitude towards the course in the study that created with qualitative method, two-stage survey study was applied in 2019-2020 Academic Year Fall Semester of Nuh Naci Yazgan University Interior Architecture and Environmental Design Department basic design education course. The first stage of the study was applied to 51 students in the third week of the semester, and the second stage to 45 students in the 14 th week. The data obtained as a result of the survey were analyzed with the SPSS program and the findings were reached. In line with the results reached by the study, it is seen that students have generally positive attitudes towards basic design education, there is no meaningful attitude change in the second stage, only male students' attitudes towards the homework of the course have changed negatively. It is a positive situation that students have positive attitudes towards the lesson and not being biased, although they have just been introduced to the lesson. However, the negative attitude towards homework reveals the necessity of updating the method of the course considering today's student profile andexpectations.
\end{abstract}

Keywords: Interior Architecture, Basic Design Education, Learning, Attitude, Attitude Change.

\footnotetext{
*Corresponding Author: iyildirim@nny.edu.tr
} 


\section{Giriş}

Tasarlamak, varları birbiriyle ilişkilendirerek bir var olmayana ulaşma çabası; bu çaba sonucunda ulaşılan var olmayan ise tasarımdır." (Öztürk, 2007) Başka bir ifadeyle tasar ya da tasarı; yapılması düşünülen nesne ya da biçimlerin zihinde oluşturulmasıdır (Aytekin, 2008).

Temel tasarım ise; sanatçıları, belirli bir sanat dalında somut verilerle belirlenen işlevlere cevap verebilecek yapitlar tasarlayıp biçimlendirmeleri sürecinde karşılaşabilecekleri çeşitli durumlara hazırlamayı amaçlayan olgudur (Özer, 2009). Başka bir deyişle temel tasarım, tasarımcı tanımı altında problem çözümleri üreten çeşitli disiplinlerden kişiler için ilk adım bilgisi taşıyan sanat, tasarım ve zanaat üretiminin yapı taşları olarak bilinmektedir (Aytekin, 2019). Temel tasarım eğitimi bireye özgü duyu, düş, sezgi, düşünce canlandırma kabiliyetini ortaya çıkaran ve bu kabiliyeti estetik bir düzen ile kullanabilen, geliştirebilen yetenek düzeylerine sahip yaratıcı kişiliklerin oluşmasını sağlayan, tasarım disiplinlerinin ortak ve başlangıç eğitim sürecidir (Gökaydın, 2010).

Temel tasarım eğitimi, aradan geçen bir asırlık süreye rağmen Bauhaus'tan günümüze kadar süregelen, sanat ve tasarım ile ilgili disiplinler için hazırlık eğitimi niteliğinde, öğrencilerin tasarıma ya da tasarım eğitimine yönelik hazırbulunuşluk düzeylerinin belirlendiği, öğrencilerin kendilerinde var olan yaratıcılığı ve yeteneği keşfederek, özgün ifade biçimleri geliştirdikleri bir derstir (Yıldırım, 2018).

Seylan'a göre ise öğrencilerin kendilerini tanımasını sağlayarak onlara yargılarını kontrol etmesini ve önyargılarından arınmalarını öğretmeyi amaçlayan bir disiplin olarak doğmuştur (Seylan, 2005). Tasarım eğitiminde ilk yıl, bireyden ortaöğrenimde elde ettiği alışkanlıklarını dönüştürmesi beklenen bir ortam olduğu için birey açısından oldukça önemlidir. Dural (1999) tarafindan bu ortam, ortaöğretimden gelen araştırma ve sorgulamayı bilmeyen, ezbere dayalı, otoriteye bağımlı, korkak bireyler yetiştiren eğitim sistemimizin bir sonucu olarak, 'çok boyutlu düşünme' eyleminin zorunluluk olduğu mimarlık eğitimi için bu kazanımların sağlanabilmesi adına büyük sorumluluklar üstelenen bir olgu olarak tanımlanmaktadır.

İç mimarlık eğitiminin bel kemiğini oluşturan Temel Tasarım eğitimi, 17. yüzyıldan günümüze kadar çeşitli değişimler ve gelişmeler göstermiştir. Bugün 'Temel Tasarım' dersi, İç Mimarlık öğrencilerinin ilk yıllarında aldıkları temel bir derstir. Tasarım eğitimi almaya başlayan öğrenciler, öncelikle alışılmışın ötesinde farklı bir dünyaya adım attıklarının farkında olmazlar, ancak deneyimle farkındalıkları arttıkça bambaşka bir dünyayı deneyimlemeye başlarlar. $\mathrm{Bu}$ süreç ağırlıklı olarak ögrencilerin tasarımı anlamasında ilk adım olan Temel Tasarım Eğitimi kapsamında gerçekleşmektedir ve giriş eğitimi olarak da adlandırılan bu eğitim, tasarımcı adayı için ilk adımdır. Bu bağlamda bu derste farkındalık yaratma, görsel duyarlılık kazanma, soru ve çözümlerin nasıl çeşitlendirilebileceğini kavrama becerileri büyük önem taşımaktadır (Esen, Elibol, \& Koca, 2018). Tüm bu özellikleriyle ise temel tasarım eğitimi, eyleme dayalı, eyleme algının dâhil edildiği, dolayısıyla öğreneni etkin kılan güncel bir temel eğitim konusudur (Özkar, 2009).

Tasarım eğitimi felsefesi, tasarım konularına bütüncül bir yaklaşımla, hem bilginin keşfinin hem de bilginin aktarılmasının önemini vurgulayarak, tasarım stüdyosunda yaratılan entelektüel e-ISSN: 2148-2683 bir atmosfer ve yaratıcı düşüncenin eleştirel düşünmeye dönüştürülmesine dayanmaktadır (Aydınlı \& Akpınar, 2003).

Geçmiş eğitim tecrübeleri ile kesin ve kalıp bilgilerin varlığını çoklukla benimseyerek mimarlık eğitimine başlayan bireye "şu ana kadar bildiğin her şeyi unut, yeniden öğrenmeye çalış" komutunun örtük bir şekilde sunulması ile deneyimsel bilginin varlığından söz etmek öğrencide büyük bir şaşkınlığa/afallamaya yol açacak ve sonuç olarak öğrencide, hem kendisi hem de çevresi ile ilgili meraklı bir bakış oluşturacaktır (Birer, 2011). Bu bakış açısı oluşurken de öğrencinin derse yönelik izlenimleri, tutumları değişebilecek ve okunabilir olacaktır. Temel tasarım eğitimi bu yapısı sebebi ile tutum tespiti yapmak için oldukça uygun bir alandır. Öğrencilerin eğitime ve öğrenmeye yönelik geçmiş alg1 ve alışkanlıklarının büyük ölçüde değişime uğrayacağı bu ders, başlangıçta alışılmadık, zor ve karmaşık gelebilen yapısı ile öğrenme ve deneyim sonucu tutum değişiminde etkili olabilecektir. Sonuçta ortaöğretim sistemiyle böylesine ters olan bu sistem tutum değişimi oluşmasında oldukça yatkındır ve bu çalışmada da böylesi önemli ve alışılmadık bir sisteme yönelik öğrenci tutumu ve bu tutumun öğrenme ve deneyimlerle değişebileceği öngörüsü ele alınmaktadır.

$\mathrm{Bu}$ öngörüden yola çıkarak tutum kavramını ve tutumun değişebilirliğini ele aldığımızda; tutum her türlü nesneye (objeye) ya da duruma verilen tepkileri doğrudan ya da dolaylı olarak etkileyebilecek deneyimler sonucu oluşturulmuş bir zihinsel hazıroluş hali ya da nesneler, konular, kişiler, gruplar ya da kurumlar hakkında kişilerin aldıkları pozisyon (Sakallı Uğurlu, 2018) şeklinde tanımlanmaktadır.

Tutum; öğrenme ile kazanılan, davranışlara yön verebilen ve karar verme sürecinde yanlılığa neden olan bir olgudur (Ayaydın ve Kurtuldu, 2010a). İnsanın karşılaştığı durum ya da durumları kabul ya da ret etmesine yönelik niyeti ve bunun sonucunda gösterdiği eğilim olan tutumlar bireyin çevresindeki herhangi bir konu, nesne ya da olaya karşı bilgi, deneyim, duygu ve motivasyonuna dayanarak gösterdiği zihinsel, duygusal ve davranışsal tepkilerdir (Aytekin, 2008). Eagly ve Chaiken (2007) tarafindan bireylerin kişisel deneyimleri aracılığıyla tutumlarını oluşturdukları ve bunların da geçmiş deneyimlerden akılda kalan zihinsel değerlendirme tortuları olduğu ileri sürülmektedir. $\mathrm{Bu}$ doğrultuda k1saca tutum bir nesne, konu ya da duruma yönelik olumlu ya da olumsuz duygu, düşünce ve davranışsal eğilimlerin, öğrenme sonucu zihinde tortulaşmış hali olarak tanımlanabilir.

Tutum ölçerken yapılan da bireyin aklında yer alan bu tortudan dolayı nasıl cevaplar verebileceğini tahmin etmektir. Tutumlar ifade edildikleri ortamdan etkilediği için tutum aynı kalsa dahi ortamın etkisinden dolayı tutum ile ilgili tepkiler ya da kararlar değişebilmektedir. Tutumlar öğrenme ve deneyimler yoluyla oluştuğu için yine aynı şekilde yaşam boyunca yeni tutumlar öğrenilebilmekte ve mevcut tutumlar değişebilmektedir (Sakallı Uğurlu, 2018). Bununla birlikte, tutumların önceki deneyimler, sosyal etkileşim ve model almaya bağlı olarak gelişmesi nedeniyle tutum nesnesi ya da olgusuna yönelik çok az bilgiye sahip olunsa da bireyler belirli tutumlara sahip olabilmektedirler (Aytekin, 2008).

Öğrenme bir problemle veya bir durum ile başa çıkma çabasıyla başlamakta olup tutumların değişmesi de öğrenme ve deneyimler ile ilgili bir süreç olduğu için çalışma temel tasarım eğitimde öğrenme ile tutumun değişebileceği öngörüsü üzerinden temellendirilerek oluşturulmuştur. Katz ve ark. göre; 
tutum işlevleri tutum değişimine neden olmaktadır ve bu nedenle de kişilerin tutumları değiştirilmek istendiğinde, kişi için işlevi bilinmelidir. Anlama ve bilgi işlevi ile ilişkili bir tutumun kolaylıkla değiştirilebilmesi için de bireyin konu hakkında net olmayan bir konumda olması yeterli olabilmektedir (Sakallı Uğurlu, 2018). Bu veriden yola çıkarak hem iç mimarlık ve çevre tasarımı bölümüne yeni başlayan öğrencilerin temel tasarım eğitimine yönelik net olmayan bir konumda olmaları hem de bu dersin önceki öğrenmelerle oldukça farklı içeriklere/işleyişlere sahip olması sebebiyle tutum değişimi bu ders üzerinden okunmaya çalışılmıştır.

Yeni bilgilerin verilmesi, çevrenin değişmesi ya da durumun muğlak hale getirilmesi tutumların değişimini sağlamaktadır. Bu işlevde önemli olan anlama ve anlamlı bilişsel düzenlemeler yapma olduğu için sorunlar için daha anlamlı bilgiler sağlama tutum değişimine neden olabilir ve bunun sonucunda da yeni bilgiler çerçevesinde birey tutamlarında düzenlemeye gidebilir (Sakallı Uğurlu, 2018).

Tutum değişimini etkileyen dört ana unsur;

- Mesajı kim verdi? (iletişim kaynağ veya konuşmacl),

- Ne söylendi? (mesaj veya iletişim),

- Nasıl iletildi? (mesajın veriliş yolu) ve

- Kime söylendi(dinleyici) (Sakallı Uğurlu, 2018:135) şeklinde ele alınmaktadır.

Bu çalışma ile de tutumun değişmesine altyapı oluşturan "ne söylendi" değişkeni ile yani öğrenme ile tutum değişikliği iç mimarlık bölümü temel tasarım eğitimi dersi üzerinden okunacaktır.

Aytekin (2008) tarafından belirtildiği gibi öğrencilerin öğrenme sürecindeki bütün davranışları ve seçimleri ile tutumları ilişkilidir ve öğrencinin etkin katılımı olmadan öğrenme gerçekleşemeyeceği için öğrencilerin öğrenme etkinliğine katılması için o alana yönelik tutumları önemli belirleyicilerdir. Ayrıca, duygusal eğilimler öğrencilerin sonraki davranışları için önemli etkenler oldukları için öğrencilerin tutumları veya ilgi alanları eğitimciler için önem arz etmektedir (Dikmen vd., 2018).

"Temel tasarım dersine yönelik tutum ise, diğer tutumlar gibi ögrencilerin temel tasarım dersi sürecindeki yaşantı ve deneyimleri, etkileşimleri sonucu oluşan ve ögrenme sürecinde değişebilen, derste ögrencilerin öğrenmelerini etkileyen ve de karar verme mekanizmasl ve davranışlar üzerinde aktif rol oynayan, temel tasarım dersine karşı duygusal, bilişsel ve davranışsal yönde olumlu ya da olumsuz tepki gösterme eğilimleridir.” (Aytekin, 2008:172).

Sonuç olarak ortaöğretim eğitim sistemimizin hazır bilgi ve ezbercilik anlayışı göz önünde bulundurulduğunda, tasarım eğitimi altyapısı olmayan öğrencilerin soyut ve karmaşık bu derslerle karşılaştıklarında zorlanmaları ve bunun sonucu derse karşı önyarg1 ya da olumsuz tutum beslemeleri kaçınılmaz görünmektedir. $\mathrm{Bu}$ çalışmada derse yönelik öğrenci tutumu yarıyıl başında ve sonunda ölçülerek öğrenme ile birlikte derse yönelik tutum değişikliği olabileceği öngörüsü ile oluşturulmuştur.

Bununla birlikte, Aytekin (2008) tarafından Resim-İş Anabilim Dalında temel tasarım eğitimine yönelik tutumu ölçmek amacıyla yapılan çalışmada da olduğu gibi; tutumların ölçülmesi ile amaç öncelikle, ögrrencilerin temel tasarım dersine e-ISSN: 2148-2683 karşı duygu analizlerini yaparak, tutumlarının ne kadar olumlu ya da olumsuz olduğunu bulmakla birlikte, henüz almış oldukları bu dersin mevcut durumuna yönelik tutumları hakkında bilgi edinmek ve mevcut durumun yönlendiriciliğinin ve etkinliğinin tartışmaya açılmasıyla iyileştirmek adına önerilerde bulunabilmektir. Çalışma ile de bu doğrultuda bir yol izlenmektedir.

Araştırma kapsamında alan yazında yer alan ilgili çalışmalar incelendiğinde ise; Taşkesen (2019) tarafından gerçekleştirilen çalışmada Güzel Sanatlar Fakültesi Resim bölümü ve Eğitim Fakültesi Güzel Sanatlar Eğitimi Resim-İş Eğitimi bölümü üzerinden öğrencilerin temel tasarım dersine yönelik tutum analizi cinsiyet ve fakülte değişkenleri aracılığıyla ölçülmüş ancak anlamlı bir fark olmadığı ve her iki fakültedeki ögrencilerin de derse yönelik olumlu tutum ve motivasyonlara sahip olduğu sonucuna ulaşılmıştır. Tülüce, tarafından 2016 yılında gerçekleştiren çalışmada, proje tabanlı öğretim yaklaşımlarının gerçekleştirildiği temel tasarım eğitiminde akademik başarının arttığı ve derse yönelik tutumun olumlu yönde etkilendiği sonucuna ulaşılmıştır. Başka bir ele alış ise Uysal, 2015 tarafından gerçekleştirilmiş ve lisans seviyesinde 1. sınıf öğrencilerin temel tasarım dersine yönelik tutum ve görüşleri tespit edilmeye çalışılmış; sonuç olarak öğrencilerin dersin kazanımlarına yönelik olumlu tutumlara sahip oldukları görülmüştür.

\section{2.Örneklem Okulda Sürdürülen Temel Tasarım Eğitimi Kapsamı ve İçeriği}

Nuh Naci Yazgan Üniversitesi İç Mimarlık ve Çevre Tasarımı Bölümü 2015-2016 eğitim öğretim yılında eğitime başlamış olup temel tasarım eğitimi dersi burada 4 saat teorik 4 saat uygulamalı olmak üzere sekiz saat sürdürülmektedir. $\mathrm{Bu}$ dersin içeriği ise şu şekilde kurgulanmıştır:

1. Hafta: Bir Nokta

2. Hafta: İki Şey

3. Hafta: Üç Geometrik Şekil

4. Hafta: Renk Çemberi

5. Hafta: Uçurtma

6. Hafta: Çok ve Güzel

7. Hafta Giriş-Geçiş-Varış

8. Hafta: Ara Sinav

9. Hafta: Mekan

10. Hafta: Metamorfoz

11. Hafta: Kombiosis

12. Hafta: Bir Yaşam Çevresi

13. Hafta: Sunuş

14. Hafta: Son Jüri

14 haftalık yarıyıla ait bu kurguda amaç, öğrencilerin önceki eğitim hayatlarındaki mutlak doğru anlayışını ve bilginin onlara hazır olarak formüllerle sunulması alışkanlığını kırmak ve onları düşünmeye, beyin firtınasına, yeni şeyler üretmeye teşvik etmek, yaratıcılık gelişimini sağlamak ve temel tasarlama yetilerini kazandırarak karşılarına çıkan ya da onlara verilen problemlerin çözümünde kendilerine özgü bir tasarım dili ya da kimlik oluşturmalarına yardımcı olmaktır. $\mathrm{Bu}$ süreç içerisinde başlangıçta bahsedilen temel tasarım ilke ve ögelerini sezgisel yollarla kavramalarını sağlayacak basitten karmaşığa doğru ilerleyen ve her biri birbirini besleyen-destekleyen, eklemlenerek ilerleyen çalışmalara yer verilmiştir. $\mathrm{Bu}$ çalışmalar ile öğrencilerde somut soyut algısı, malzemeye anlam yükleme, 
birbirinden farklı birden fazla nesne ile anlamlı bir bütün oluşturma, sınırları belirleme ve tanımlama, ölçü-ölçek, oranorantı gibi kazanımların sağlanması hedeflenmektedir. $\mathrm{Bu}$ kazanımlar sağlanırken de aslında ilk başta öğrencilere oldukça kompleks, soyut, anlamsız, zor gelebilen bu derse yönelik önyargıyı kırabilmektir.

Örneklem okulda sürdürülen proje içeriklerine kısaca değinilecek olursa; Şekil 1'de yer alan iki şey çalışması ile öğrencilerin temel anlamda birbiriyle ilişkili ya da ilişkisiz iki şeyi bir araya getirerek anlamlı bir kompozisyon oluşturma, bütüne varma yetilerinin gelişmesi amaçlanmaktadır. Benzer şekilde Şekil 2'de yer alan 3 geometrik şekil çalışmasında da veri sayısı ikiden üçe çıkarılarak aynı ilişkiler ağı beklenmiş̧ir. Şekil 3'teki renk çemberi çalışmasında ise öğrencilerin temel anlamda renk bilgisi edinmeleri amaçlanmaktadır. Şekil 4'teki uçurtma çalışması ile o ana dek öğrenilen verilerden de faydalanılarak yine bir kompozisyon oluşturulması ancak bu kez işlevin de bu sürece dâhil olması beklenmektedir. Bu doğrultuda öğrenciden uçma işlevini yerine getirebilecek bir kompoziyon ortaya koyması istenmektedir. Sonrasında çok ve güzel çalışmasıyla (Şekil 5) ise bir ögeyi çoğaltarak ondan nasıl anlamlı ve 'çok-güzel' kavramlarına yanıt olabilecek bir bütün oluşturabileceklerine yönelik bir sonuç ürün istenmektedir. Takip eden süreçte Şekil 6'da da görüldüğü üzere giriş ve varış (bitiş ) tanımının oluşturulan kompozisyonda nasıl vurgulanabileceği, aslında başlangıçta aynı gibi algılanan giriş ve varış arasındaki farkın nasıl ifade edilebileceğine yönelik bir keşif sürecine yer verilmektedir. Ardından mekân çalı̧̧ması (Şekil 7) ile soyut, kapalı-açık hacimleri barındıran (dolu-boş ilişkisi), dinamik bir mekân oluşturmaları üzerine kurgulanan bir çalışmaya yer verilmektedir. Sonrasında ise metamorfoz yani başkalaşma kavramının bir kompozisyonda nasıl ifade edilebileceği (Şekil 8), iki şeyin birbiriyle ilişkili bir birlikteliği nasıl oluşturabileceği-kombiosis (Şekil 9) ve hayali bir yaratık ya da kullanıcı için bir yaşam çevresi tasarlanması (Şekil 10) şeklinde ele alışlara yer verilmiştir.

Şekil 1. 'İki şey' çalışması

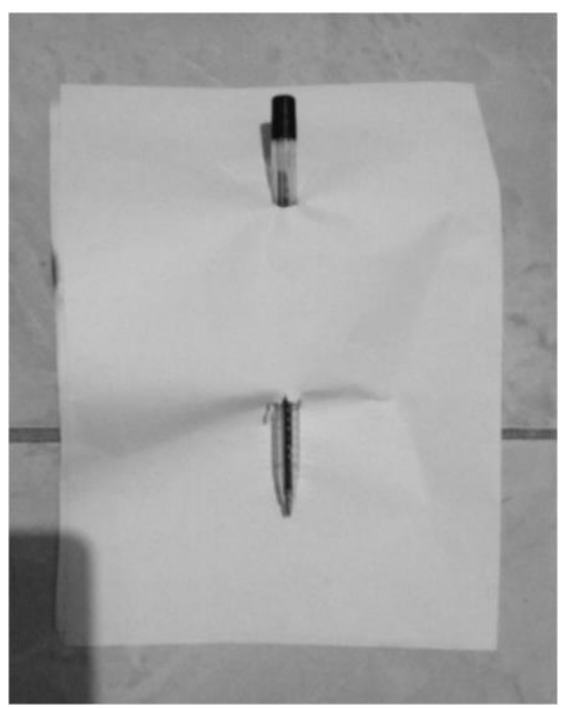

Şekil 2. 'Üç Geometrik Şekil' Çalışması

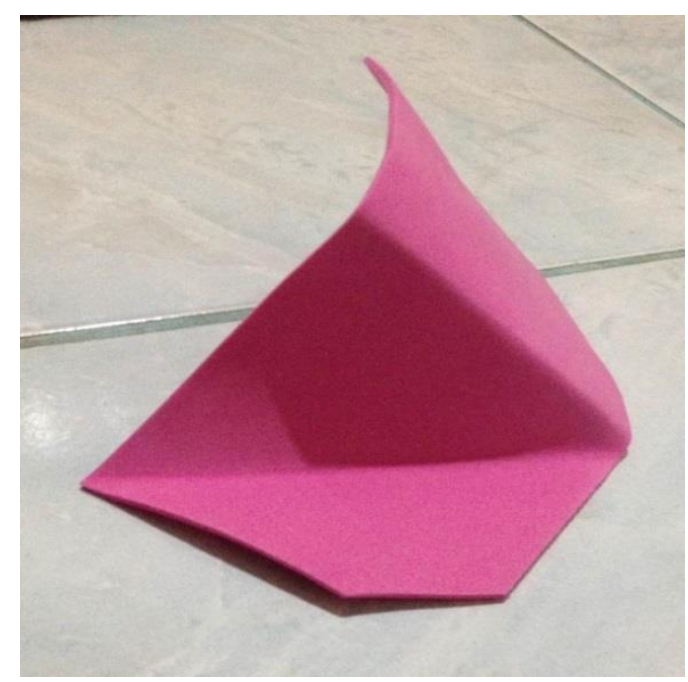

Şekil 3. 'Renk Çemberi' Çalışması

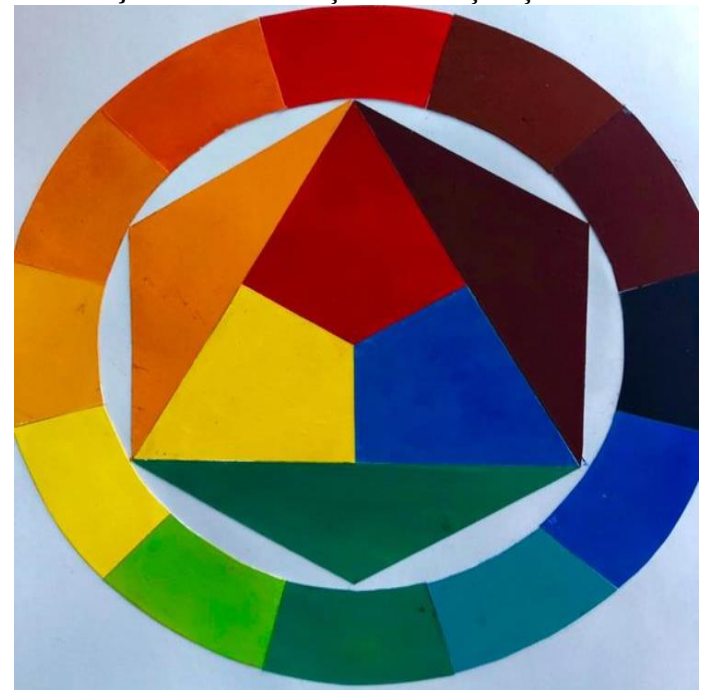

Şekil 4. 'Uçurtma' Çalışması

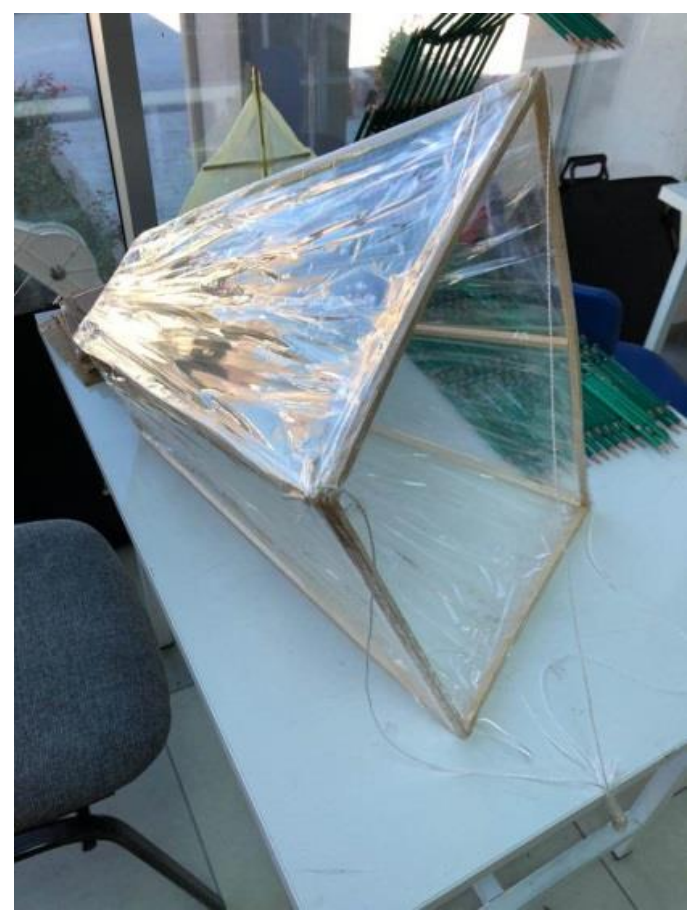


Şekil 5. 'Çok ve Güzel' Çalışması

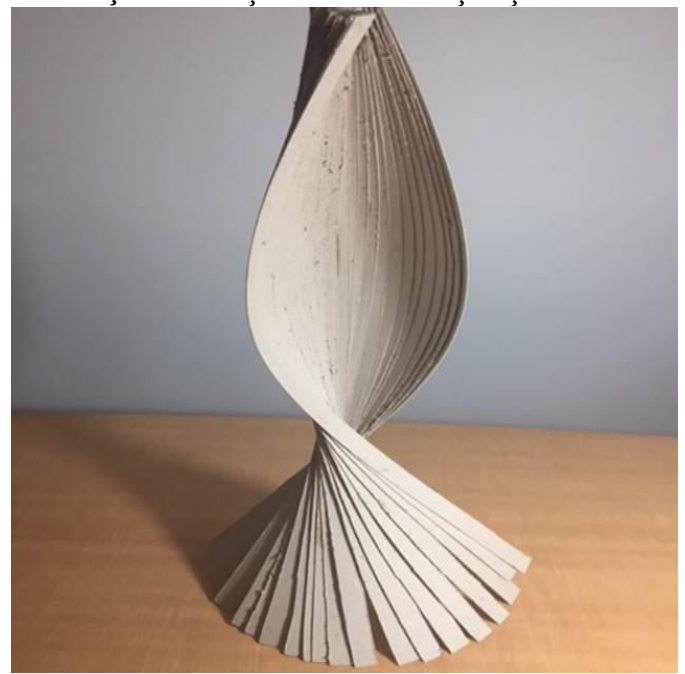

Şekil 6. 'Giriş-Geçiş-Varış’ Çalışması



Şekil 7. 'Mekan' Çalışması

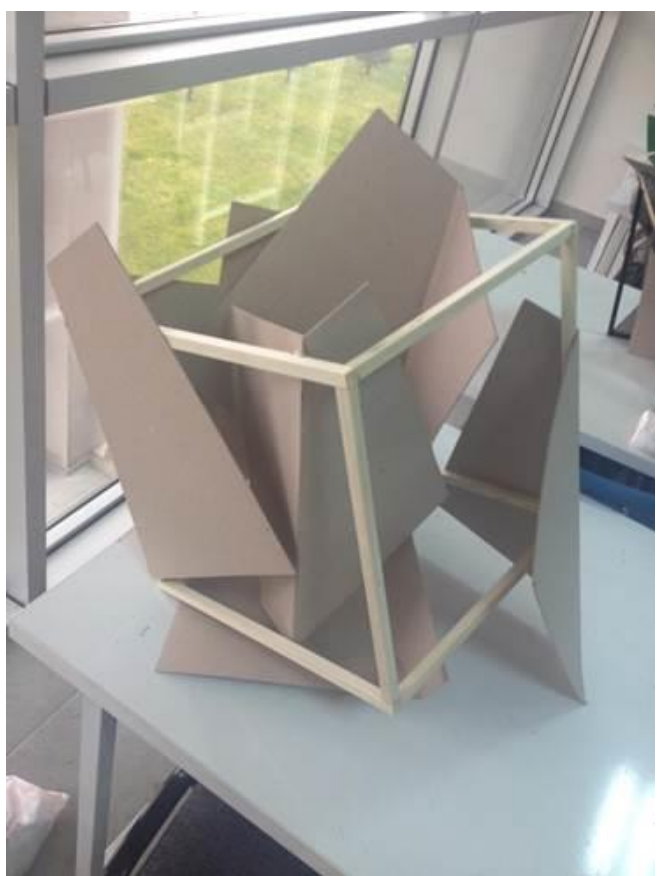

Şekil 8. 'Metamorfoz’ Çalışması

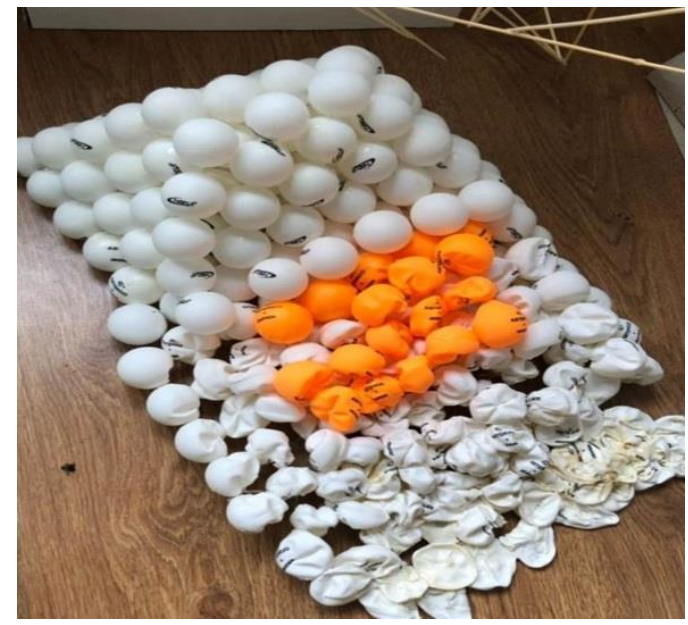

Şekil 9. 'Kombiosis’ Çalışması

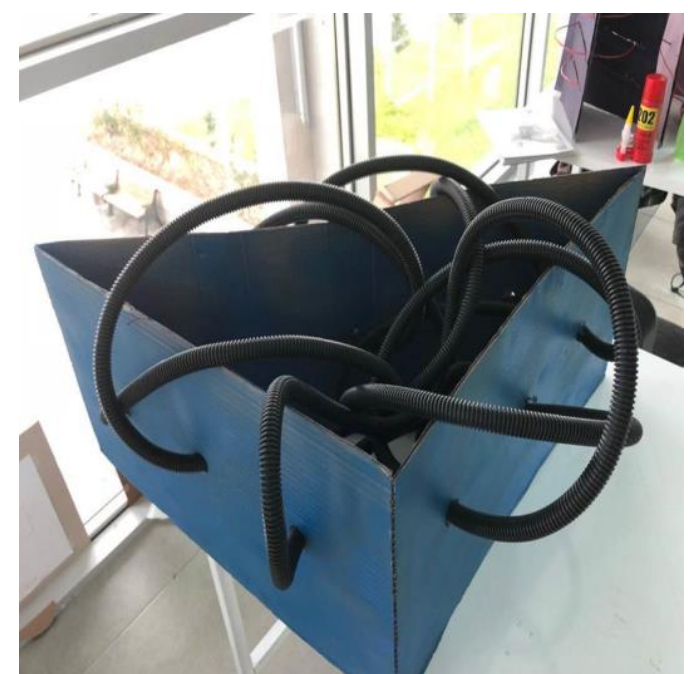

Şekil 10. 'Bir Yaşam Çevresi' Çalışması



\section{Amaç}

Eğitimle ilgili tüm disiplin ve çalışmalarda serzenişte bulunulan sorgulamayan ve ezbere dayalı eğitim sisteminin ardından; temel tasarım eğitimi ile ilk kez karşılaşan öğrenci bu sistemi anlamakta güçlük çekmekte ve önyarg1 ile 
yaklaşabilmektedir. Bu çalışma, bu eğitimin başlangıcında ve sonunda öğrencilerin bu derse karşı tutumlarını ölçerek öğrenme sonucu meydana gelen değişimleri tespit etmeyi amaçlamaktadır.

\section{Yöntem}

\section{1. Örneklem}

Çalışma, 2019-2020 eğitim-öğretim yılı güz yarıyılında, Nuh Naci Yazgan Üniversitesi Güzel Sanatlar ve Tasarım Fakültesi İç Mimarlık ve Çevre Tasarımı Bölümü'nde lisans düzeyinde eğitim gören temel tasarım eğitimi dersini alan 96 öğrenci ile gerçekleştirilmiştir. Tablo 1'de görüldüğü üzere çalışmanın birinci aşamasında 51, ikinci aşamasında ise 45 öğrenciye anket çalışması uygulanmıştır ve çalışmaya katılan öğrencilerin cinsiyet dağılımını ise Tablo 2'de yer aldığ 60 kadın, 30 erkek öğrenci oluşturmaktadır.

\section{Tablo 1. Çalıșma Örneklem Grubu}

\section{DURUM}

\begin{tabular}{|ll|l|l|l|l|}
\hline & & $\begin{array}{l}\text { Frequenc } \\
\text { y }\end{array}$ & Percent & $\begin{array}{l}\text { Valid } \\
\text { Percent }\end{array}$ & $\begin{array}{l}\text { Cumulative } \\
\text { Percent }\end{array}$ \\
\hline Valid & 3.Hafta & 51 & 53,1 & 53,1 & 53,1 \\
& 14.Hafta & 45 & 46,9 & 46,9 & 100,0 \\
& & & & \\
& Total & 96 & 100,0 & 100,0 & \\
\hline
\end{tabular}

Tablo 2. Çalışmaya Katılan Öğrencilerin Cinsiyete Göre Dă̆ılımı

\section{CINSIYYT}

\begin{tabular}{|c|l|l|l|l|}
\hline & Frequency & Percent & $\begin{array}{l}\text { Valid } \\
\text { Percent }\end{array}$ & $\begin{array}{l}\text { Cumulative } \\
\text { Percent }\end{array}$ \\
\hline Valid Kadın & 60 & 62,5 & 62,5 & 62,5 \\
Erkek & 36 & 37,5 & 37,5 & 100,0 \\
Total & 96 & 100,0 & 100,0 & \\
\hline
\end{tabular}

\subsection{Araştırma Problemi}

Araştırmada "Temel tasarım eğitiminde öğrenme ve deneyimin derse yönelik tutuma etkisi var mıdır?" sorusuna yanıt aranmakta ve bu sorgulama araştırmanın problemini oluşturmaktadır.

\subsection{Veri Toplama Araçları ve Verilerin Analizi}

Çalı̧̧ma nitel yöntem ile şekillendirilmiş olup, yardımcı teknik olarak tarama modeli ile kaynak taraması yapılarak çalışmanın literatür kısmı oluşturulmuştur. Veri toplama yöntemi olarak anket tekniğinden faydalanılan çalışmada anket soruları oluşturulurken literatürde bu konuda yer alan, Aytekin tarafindan 2008 yılında resim-iş eğitimi anabilim dalı alanında gerçekleştirilmiş olan çalışmadan ve tutum ölçmeye yönelik diğer çalışmalardan (Ayaydın ve Kurtuldu, 2010b) faydalanılmıştır.

Elde edilen veriler, SPSS paket programı yardımıyla analiz edilmiş, korelasyon ve ANOVA kullanılarak değerlendirilmiştir. Veriler değerlendirilirken kullanılan ölçek için tercih edilen likert tipi beşli cevap seçeneklerinin dağılım puanlarına tablo 3 'te yer verilmiş ve hangi maddenin hangi tutum puanı aralığına geldiğini gösteren bu tablo/ölçek yardımıyla bulgular kısmındaki tablolar yorumlanmıştır.

e-ISSN: 2148-2683

Tablo 3. Likert Ölçek Puan Aralıkları

\begin{tabular}{ll} 
ÖLÇEK & PUAN \\
& ARALIKLARI \\
\hline Kesinlikle katıllyorum & $0,00-1,00$ \\
Kat1lyorum & $1,00-2,00$ \\
Kararsızım & $2,00-3,00$ \\
Katılmıyorum & $3,00-4,00$ \\
Kesinlikle katılmiyorum & $4,00-5,00$ \\
\hline
\end{tabular}

\section{Bulgular}

Bu bölümde örneklem grubun sorulara verdikleri cevapların faktörlere yönelik ölçüm sonuçlarını gösteren tablolar yer almaktadır. Oluşturulan tablolarda sorulara ait ortalama tutum puanları verilmiş ve değerlendirmeler bu puanlara yönelik gerçekleştirilmiştir.

Tablo 4. Temel Tasarım Eğitimi İle İlgili Sorulara Yönelik Tutum Puanlarl

\section{MADDELER/SORULAR}

1.Temel tasarım eğitimi keyifli bir derstir.

2.Temel tasarım eğitimi önemli bir derstir.

3.Temel tasarım eğitimi dersi sıkıcıdır.

4.Temel tasarım eğitimi dersi ödevleri sıkıcıdır.

kavramları kazandırılır.

6.Temel tasarım eğitimi çalışmaları kolaydır.

7.Temel tasarım eğitimi dersini ilginç buluyorum.

8.Temel tasarım eğitimi dersini eğitim hayatı için önemli ve gerekli buluyorum.

9.Temel tasarım eğitimi dersini meslek hayatı için 1,62 önemli ve gerekli buluyorum.

10.Temel tasarım eğitimi dersi çalışmalarını yeterli ve 2,09 verimli buluyorum.

Tablo 4 incelendiğinde öğrencilerin genel eğilim itibariyle olumlu, kısmen de kararsız bir eğilim gösterdikleri görülmektedir. Tablo 4'te yer alan ortalama tutum puanlarının kararsızım, katılıyorum ve kesinlikle katılıyorum seçeneğini işaret ettiği görülmektedir. Öğrencilerin dersin önemine ve gerekliliğine yönelik görüşlerinde belirleyici sorular olarak görebileceğimiz dersin eğitim hayatı ve sonrası için gerekliliği ve dersten hoşlanmaya dayalı maddelerde öğrencilerin olumlu bir tutum sergiledikleri ortaya çıkmıştır. Öğrenciler dersin ödevlerine ve kolaylığına yönelik sorularda kararsız tutum sergilerken diğer sorulara verdikleri cevaplarla dersin önemi, gerekliliği ve ders içeriğinin yeterliliğine yönelik olumlu bir tutum içerisinde olduklarını ifade etmişlerdir.

Tablo 4 incelendiğinde ortalama tutum puanlarının kesinlikle katılıyorum ve katılıyorum seçeneklerinde yoğunlaştığı görülmektedir. Öğrencilerin temel tasarım eğitimi dersinin kolaylığı ve ödevlerinin zorluk ve sıkıcılığına yönelik genel olarak kararsız oldukları fakat genel anlamda dersin gerekliliği, kazanımları, hem eğitim hem de meslek hayatı açısından önemli olduğuna yönelik maddelerde olumlu tutum sergilediklerini söylemek mümkündür. 
Tablo 5.Haftalara Göre Derse Yönelik Tutum Puanları ve Analiz Sonuçları

\begin{tabular}{|c|c|c|c|c|c|c|}
\hline & & $\begin{array}{l}\text { Sum of } \\
\text { Squares }\end{array}$ & $\mathrm{df}$ & $\begin{array}{l}\text { Mean } \\
\text { Squar } \\
\text { e }\end{array}$ & $\mathrm{F}$ & Sig. \\
\hline S1 & $\begin{array}{l}\text { Between Groups } \\
\text { Within Groups } \\
\text { Total }\end{array}$ & $\begin{array}{l}, 824 \\
105,135 \\
105,958 \\
\end{array}$ & $\begin{array}{l}1 \\
94 \\
95 \\
\end{array}$ & $\begin{array}{l}, 824 \\
1,118\end{array}$ & ,736 & ,393 \\
\hline S2 & $\begin{array}{l}\text { Between Groups } \\
\text { Within Groups } \\
\text { Total }\end{array}$ & \begin{tabular}{|l|}
1,112 \\
62,627 \\
63,740 \\
\end{tabular} & $\begin{array}{l}1 \\
94 \\
95\end{array}$ & $\begin{array}{l}1,112 \\
, 666\end{array}$ & 1,669 & ,200 \\
\hline$\overline{S 3}$ & $\begin{array}{l}\text { Between Groups } \\
\text { Within Groups } \\
\text { Total }\end{array}$ & $\begin{array}{l}, 261 \\
105,739 \\
106,000\end{array}$ & $\begin{array}{l}1 \\
94 \\
95\end{array}$ & $\begin{array}{l}, 261 \\
1,125\end{array}$ & ,232 & ,631 \\
\hline \begin{tabular}{|l|}
$S 4$ \\
\end{tabular} & $\begin{array}{l}\text { Between Groups } \\
\text { Within Groups } \\
\text { Total }\end{array}$ & $\begin{array}{l}, 137 \\
130,821 \\
130,958\end{array}$ & $\begin{array}{l}1 \\
94 \\
95\end{array}$ & $\begin{array}{l}137 \\
1,392\end{array}$ & ,099 & ,754 \\
\hline \begin{tabular}{|l|} 
S5 \\
\end{tabular} & $\begin{array}{l}\text { Between Groups } \\
\text { Within Groups } \\
\text { Total }\end{array}$ & \begin{tabular}{|l|}
018 \\
38,722 \\
38,740 \\
\end{tabular} & $\begin{array}{l}1 \\
94 \\
95 \\
\end{array}$ & $\begin{array}{l}, 018 \\
412\end{array}$ & ,044 & ,835 \\
\hline S6 & $\begin{array}{l}\text { Between Groups } \\
\text { Within Groups } \\
\text { Total }\end{array}$ & \begin{tabular}{|l|}
1,059 \\
86,931 \\
87,990 \\
\end{tabular} & $\begin{array}{l}1 \\
94 \\
95 \\
\end{array}$ & $\begin{array}{l}1,059 \\
, 925\end{array}$ & 1,145 & 287, \\
\hline $\bar{S} 7$ & $\begin{array}{l}\text { Between Groups } \\
\text { Within Groups } \\
\text { Total }\end{array}$ & \begin{tabular}{|l|}
316 \\
79,684 \\
80,000 \\
\end{tabular} & $\begin{array}{l}1 \\
94 \\
95 \\
\end{array}$ & $\begin{array}{l}316 \\
, 848\end{array}$ & ,373 & ,543 \\
\hline \begin{tabular}{|l|} 
S8 \\
\end{tabular} & $\begin{array}{l}\text { Between Groups } \\
\text { Within Groups } \\
\text { Total }\end{array}$ & \begin{tabular}{|l|}
417 \\
83,323 \\
83,740 \\
\end{tabular} & $\begin{array}{l}1 \\
94 \\
95 \\
\end{array}$ & $\begin{array}{l}417 \\
, 886\end{array}$ & ,470 & ,495 \\
\hline S9 & $\begin{array}{l}\text { Between Groups } \\
\text { Within Groups } \\
\text { Total }\end{array}$ & \begin{tabular}{|l|}
346 \\
50,154 \\
50,500 \\
\end{tabular} & $\begin{array}{l}1 \\
94 \\
95 \\
\end{array}$ & $\begin{array}{l}, 346 \\
, 534\end{array}$ & 648 &, 423 \\
\hline S10 & $\begin{array}{l}\text { Between Groups } \\
\text { Within Groups } \\
\text { Total }\end{array}$ & \begin{tabular}{|l|}
, 026 \\
84,131 \\
84,156 \\
\end{tabular} & $\begin{array}{l}1 \\
94 \\
95\end{array}$ & $\begin{array}{l}, 026 \\
895\end{array}$ & ,029 & ,866 \\
\hline
\end{tabular}

Tablo 6.Derse Yönelik Tutum Değerinin Cinsiyete Göre Analizi

ANOVA

\begin{tabular}{|ll|l|l|l|l|l|}
\hline & & $\begin{array}{l}\text { Sum of } \\
\text { Squares }\end{array}$ & df & $\begin{array}{l}\text { Mean } \\
\text { Square }\end{array}$ & F & Sig. \\
\hline S1 & Between Groups & 2,025 & 1 & 2,025 & 1,831 &, 179 \\
& Within Groups & 103,933 & 94 & 1,106 & & \\
& Total & 105,958 & 95 & & & \\
\hline S2 & Between Groups &, 201 & 1 &, 201 &, 297 &, 587 \\
& Within Groups & 63,539 & 94 &, 676 & & \\
& Total & 63,740 & 95 & & & \\
\hline S3 & Between Groups & 2,844 & 1 & 2,844 & 2,592 &, 111 \\
& Within Groups & 103,156 & 94 & 1,097 & & \\
& Total & 106,000 & 95 & & & \\
\hline S4 & Between Groups & 5,136 & 1 & 5,136 & 3,837 &, 053 \\
& Within Groups & 125,822 & 94 & 1,339 & & \\
& Total & 130,958 & 95 & & & \\
\hline S5 & Between Groups &, 156 & 1 &, 156 &, 381 &, 539 \\
& Within Groups & 38,583 & 94 &, 410 & & \\
& Total & 38,740 & 95 & & & \\
\hline
\end{tabular}

\begin{tabular}{|ll|l|l|l|l|l|} 
S6 & Between Groups &, 084 & 1 &, 084 &, 090 &, 765 \\
& Within Groups & 87,906 & 94 &, 935 & & \\
& Total & 87,990 & 95 & & & \\
\hline S7 & Between Groups &, 400 & 1 &, 400 &, 472 &, 494 \\
& Within Groups & 79,600 & 94 &, 847 & & \\
& Total & 80,000 & 95 & & & \\
\hline S8 & Between Groups & 2,256 & 1 & 2,256 & 2,603 &, 110 \\
& Within Groups & 81,483 & 94 &, 867 & & \\
& Total & 83,740 & 95 & & & \\
\hline S9 & Between Groups & 1,344 & 1 & 1,344 & 2,571 &, 112 \\
& Within Groups & 49,156 & 94 &, 523 & & \\
& Total & 50,500 & 95 & & & \\
\hline S1 & Between Groups &, 584 & 1 &, 584 &, 657 &, 420 \\
0 & Within Groups & 83,572 & 94 &, 889 & & \\
& Total & 84,156 & 95 & & & \\
\hline
\end{tabular}

Öte yandan Tablo 5 'te görüldüğü üzere haftalara göre başlangıçta ve sonrasında tutum değerlerinde anlamlı değişim görülmemektedir. Tablo 6'deki veriler incelendiğinde ise sadece dördüncü soruda ilk aşama ve ikinci aşama arasında erkek öğrencilerde anlamlı tutum değişimi olduğu görülmektedir. $\mathrm{Bu}$ değişim ise öğrencilerin dersin ödevlerini sıkıcı bulmalarına yönelik tutumlarının olumsuz yönde değişmesinden kaynaklanmaktadır.

Tüm sorularda erkek öğrenci ve kız öğrenci tutumu genel olarak birbirine yakınken dördüncü soruda cinsiyete göre anlamlı bir sonuç elde edilmiștir ve erkek öğrenciler, kız ögrencilere göre daha olumsuz cevap vermişlerdir. Bu da erkek öğrencilerin temel tasarım eğitimi dersi ödevlerini daha sıkıcı bulduklarını göstermektedir.

Tablolar incelenerek sorulara yönelik genel eğilim göz önünde tutulduğunda ise, öğrencilerin başlangıç aşamasında ve son aşamada dersin önemine, gerekliliğine yönelik olumlu eğilim gösterdiği, bununla birlikte dersin ve ödevlerinin sıkıcılığ 1 ve çalışmaların kolaylığ konusunda kararsız oldukları görülmektedir. Sadece dördüncü soru yani 'temel tasarım eğitimi dersi ödevleri sıkıcıdır' sorusunda erkek öğrencilerin çalışmanın ikinci aşamasında tutumlarının olumsuz yönde değiştiği tespit edilmiştir. $\mathrm{Bu}$ veriler öğrencilerin dersin önemi ve gerekliliğine belli oranda inandıkları, derste sürdürülen çalışmaları yeterli buldukları fakat ödevlere yönelik olumsuz tutum geliştirdiklerini göstermektedir. $\mathrm{Bu}$ durum göz önünde bulundurulduğunda ögrencilerin dersi gerekli ve önemli buldukları fakat genel anlamda kolaylığı ve sıkıcılığı konusunda kararsız oldukları, erkek öğrencilerin ise ikinci aşamada başlangıca göre dersin ödevlerini daha sıkıcı bulduklarını bu nedenle olumsuz tutuma sahip olduklarını göstermektedir.

\section{Sonuç, Tartışma ve Öneriler}

Eğitim kalitesini artırabilme, öğrenmeyi kolaylaştırabilme ve derse katılımı sağlayabilmek adına öğrencilerin derslere yönelik tutumlarını belirlemek ve elde edilen sonuçlar doğrultusunda önerilerde bulunmak ya da değiş̧ikliklere yönelmek eğitimin gelişebilmesi adına önemli ve gereklidir. $\mathrm{Bu}$ gerekliliği iç mimarlık bölümlerindeki temel tasarım eğitimi dersi çerçevesinde sınırlandırıp ele alarak, belirtilen derse yönelik öğrenci tutumunu tespit etmeyi amaçlayan çalışma sonucunda, belirlenen örneklemde öğrencilerin derse yönelik başlangıç tutumlarının genel anlamda olumlu olduğu ve öğrencilerin bu dersin öneminin bilincinde oldukları sonucuna 
ulaşılmıştır. Temel tasarım eğitiminin bu disiplin için önemi ve gerekliliği göz önünde bulundurulduğunda öğrencilerin derse karşı önyargısız olmaları pozitif bir durumdur. Bununla birlikte ilerleyen süreçlerde öğrencilerin derse yönelik tutumlarında anlamlı değişiklik olmaması ve dersin ödevlerine yönelik erkek öğrencilerin tutumlarının olumsuz yönde değişmesi üzerinde durulması gereken noktalardandır.

Öğrenme ve deneyim ile tutumun değişebileceği temelinden yola çıkan çalışmada ikinci aşamada yapılan anket çalışmasında anlamlı, herhangi olumlu ya da olumsuz bir tutum değişikliği meydana gelmemiştir. Öğrencilerin başlangıçta derse yönelik olumlu tutumlara sahip olduğu düşünüldüğünde ikinci aşamada anlamlı herhangi bir değişim olmaması hem olumlu hem de olumsuz sonuçlara işaret etmektedir. Olumlu yönü öğrencilerin başlangıçta bu dersin önemine dair fikre sahip olması ve olumlu tutumlar beslemesi ve bu olumluluğu korumuş olması iken; olumsuz yönü ise ders içerikleri ile birlikte tutumlarında anlamlı bir değişiklik olmaması ve erkek öğrencilerde ödevlere yönelik tutumlarının olumsuz şekilde değişmesidir. $\mathrm{Bu}$ durum ders içeriklerinin ve dersin yönteminin gözden geçirilmesi gerekliliğini göstermektedir. $\mathrm{Bu}$ doğrultuda sıkıcı bulunan ödevler daha eğlenceli ve verimli hale nasıl getirilebilir ya da zaten belirli bir seviyede olumlu olan tutum nasıl daha da iyileştirilebilir soruları üzerinde durulması gerekmektedir.

Söz konusu çalışma sonucu elde edilen veriler doğrultusunda öğrencilerin bu dersin öneminin ve gerekliliğinin farkında oldukları fakat dersin ve ödevlerin s1kıcılı̆̆ konusunda kararsız oldukları ikinci aşamada da dersin önemi konusunda tutumlarda anlamlı değişiklik olmadığı, fakat erkek öğrencilerin ilerleyen haftalarda dersin ödevlerini daha sıkıcı buldukları sonucuna ulaşılmıştır. $\mathrm{Bu}$ sonuçlar tutarlı sayılabilir olmakla birlikte öğrencilerin dersin önemi konusunda bilinçli olup ödevleri sıkıcı bulmaları ve bunun öğrenme sonucu ortaya çıkması aslında ders içeriğinin tekrar gözden geçirilmesi gerekliliğini düşündürmektedir. Ayrıca, Ranjan'ın (2005) çalışmasında belirttiği gibi, yaşanılan çağın tasarım araçları ve süreçlerinden yararlanılması da yapılan uygulamaların anlamlı bulunması durumuna katkı sağlayabilecek niteliktedir. $\mathrm{Bu}$ doğrultuda öğrenciler için bu denli önemli olan ve bunun farkında oldukları dersi daha etkin ve dikkat çekici kılabilmek adına farklı yöntemler denenmeli ve önerilmelidir. Bununla birlikte öğrencilerdeki tutum değişikliği olmama sebebinin not kaygısı ya da parçalı projelerden kaynaklı olabileceği de düşünülmektedir. Çünkü birden fazla projenin yer aldığı içerikte öğrenci her çalışmada başarılı sonuçlar elde edemediğinde tutumu ve algısı da sürekli değişmekte bu da anlamlı bir sonuç elde etmeye engel olabilmektedir. $\mathrm{Bu}$ nedenle öğrenmenin, algının, tutumun ve bunlardaki değişimin test edilebilmesi adına daha uzun soluklu ya da süreçli çalışmalardan faydalanılarak çalışma tekrarlanabilir ve sonuçlar karşılaştırılabilir.

Öte yandan örneklem grubun ders içeriğinde yer alan çalışmalar kendi içerisinde tutarlı ya da katkı sağlayıcı olsa dahi totalde öğrencilerdeki tutum değişimine etkisine baktığımızda anlamlı bir sonuç elde edilemediği görülmektedir. Bu durum şu soruları ya da sorgulamaları da akla getirmektedir; öğrencilerin temel tasarım eğitimine yönelik tutumu değişmediğine göre öğrenme gerçekleşmemiş olabileceği gibi öğrencinin baştan bu dersin önemini idrak ettiği ve derse karşı ilgisini tutumunu tutarlı olarak devam ettirdiği de düşünülebilmektedir. Elde edilen sonuca getirilebilecek bir başka yorum ise; Akşid (2011) tarafından belirtildiği şekilde 'Duyuşsal özelliklerle başarı arasındaki korelasyonun belli bir sınıf ya da okul yılında çok az e-ISSN: 2148-2683 bir değişme göstermesi, bir dersle ilgili birkaç yıllık yaşantı ile bir kez gelişen duyuşsal özelliklerin bundan sonra artı çok az bir değişmeye uğrayabileceğini gösterir olması ile açıklanabilmektedir.' Bu sonuç, dersle ilgili ilgi ve tutumların değişmeye dirençli olması sebebi ile anlamlı değişim olmadığını göstermektedir (Akşid ve Şahin, 2011:21).

Çalışma sonucu elde edilen sonucun bir diğer temel nedeni de ilgi ve tutumların değişmeye dirençli olması, bu değişimin gerçekleşebilmesi için de öğrencinin belli tipten öğrenme üniteleriyle ilgili yaşantılarının artmasıdır. Bunun için de öğretim hizmetinin niteliğini, öğrencilerin çoğunluğunu başarılı k1lıp onlara bu hissi vererek, öğrencinin ünitedeki başarılı yaşantıların başarısız yaşantılara oranını yüksek tutarak başarıyı vurgulayan öğretim ve not verme uygulamalarının sonraki öğrenmeler için daha olumlu duyuşsal başlangıç özellikleri sağlaması (Başbay \& Senemoğlu, 2009) olarak gösterilebilmektedir. Bu tarz bir eğitim sistemi ile ilgili öğrenci deneyimleri yeterli olmadığ 1 için Akşid'in sonucu bu çalışmadan elde edilen sonucun gerekçesi ya da destekleyicisi olarak gösterilebilmektedir. Bununla birlikte derslerin yaparak öğrenmeye dayalı olması nedeniyle öğrencilerden istenilen çalışmaların fazla olması erkek öğrencilerde meydana gelen olumsuz yönde tutum değişiminin nedeni olarak görülmekte ve bu sonuç Emsen vd., (2011) tarafından gerçekleştirilen çalışmada yer alan zamanla ödevlere yönelik tutumun olumsuz yönde değişmesi ve Hasırcı \& Coşkun Onan (2020) tarafından gerçekleştirilen çalışmadaki teori ve uygulamaların yoğunluğu nedeniyle öğrencilerin dersi zor ve sıkıcı bulduklarını ve derse ilişkin genel tutum olarak kararsız kaldıkları durumlarıyla örtüşmektedir. $\mathrm{Bu}$ doğrultuda ders içeriğinin ve ödevlerinin günümüz öğrencileri için nasıl daha kolay ve dikkat çekici olabilecek şekilde güncellenebileceği ve Hasırcı \& Coşkun Onan (2020) tarafından önerildiği şekilde ilk dönemlerdeki uygulamaların yoğunluğunu azaltarak, dersi sıkıcı bulan öğrenci sayısının düşürebileceği ve daha verimli bir öğrenme sağlanabileceği noktaları üzerinde durulmalıdır. Ayrıca içerisinde bulunduğumuz teknoloji/bilgi çağında $\mathrm{z}$ kuşağına hitap eden bu dersin halen geleneksel sayılabilecek yöntem ve yaklaşımlarla sürdürülüyor olması, teknolojiden faydalanılmıyor olması da bu noktalarda güncellemelerin gerekli olduğu düşündürmektedir.

Temel tasarım eğitimine yönelik mevcut öğrenci tutumunu belirlemek ve bu tutumun bir yarıyıllık süreçte ne şekilde evirildiğini tespit etmek kurgusu ile oluşturulan çalışmada, öğrencilerin henüz dersin başında iken bu dersin eğitim hayatları için ne kadar önemli ve altyapı oluşturucu nitelikte olduğunun bilincinde oldukları ve genel olarak derse yönelik olumlu tutumlara sahip oldukları, sonrasında ise derse yönelik genel tutumlarında olumlu ya da olumsuz anlamlı değişiklikler olmadığı sadece erkek öğrencilerin ödevlere yönelik tutumlarının olumsuz yönde değiştiği tespit edilmiştir.

Azizoğlu \& Çetin'in (2009) de belirttiği gibi tutum ve motivasyonun birbirini etkilediği ve sonuç olarak her ikisinin de öğrenci başarısını etkilediği göz önünde bulundurulduğunda, öğrencilerin daha olumlu tutumlar geliştirmesi adına etkinliklerin planlanması ve bu doğrultuda uygulanması gerekmektedir. Çalışma bir yönden bu alt amaçla gerçekleştirilmiş olup başlangıçta derse yönelik tutumun belirlenmesi ve ardından bir yarıyıllık süreçte ders içeriğiyle birlikte tutum değişiminin tespiti ile içeriğin etkililiği ölçülmüş ve eksiklikler, gereklilikler, güncellenmesi gereken noktalar tespit edilmiştir. 
Tüm bu veriler ve literatürdeki benzer çalışmalardan elde edilen sonuçlara göre; duyuşsal özelliklerle başarı arasındaki korelasyonun belirli bir sınıf ya da okul yılında çok az bir değişim gösterdiği ve bu nedenle de çalışmada, 14 hafta gibi kısa bir süre sonunda belirlenen derse yönelik tutumda anlamlı değişme gözlenememesinin nedeninin bu durumdan ve dersle ilgili ilgi ve tutumların değişmeye dirençli olması, yeni tanışılan bu öğrenme sistemine yeterince aşina olunmaması, ders içeriğinin yetersiz olması, öğrenci profilinin etkisi gibi etmenlerden kaynaklı olabileceği sonucuna varılmıştır. $\mathrm{Bu}$ doğrultuda; çalışma ile ulaşılan tespitler sonucu tutumların iyileştirilebilmesi adına yapılacak öneriler ise; ders içeriklerinin gözden geçirilmesi ve daha etkili olabilmesi için ne tür yaklaşımlar ya da içeriklerle ele alınacağı üzerinde durulması, öğrenci beklentileri ve geri dönüşlerinin göz önünde bulundurulması, öğretim yöntemleri ve içeriklerinin güncel koşullara uygun olması ile günümüz kuşağı öğrencilerine hitap edebilir olması şeklindedir. Bununla birlikte çalışmanın aynı içerikle farklı bir üniversitede ya da aynı örneklem grubunda uzun soluklu bir proje içeriği ile yahut farklı (teknoloji kullanımını içeren) bir yöntem ile uygulanması sonucu bu değişkenlerin tutuma etkisinin ölçülmesi diğer araştırmacılara konu olarak önerilmektedir. Bu sayede iç mimarlık alanında bu konu ile ilgili literatüre katkı sağlanılacağı düşünülmektedir.

\section{Kaynakça}

Akşid, F., \& Şahin, C. (2011). Coğrafya Öğretiminde Aktif Öğrenmenin Akademik Başarı ve Tutum Üzerine Etkisi. Batı Anadolu Eğitim Bilimleri Dergisi. 2(4), s.1-26.

Ayaydın, A., \& Kurtuldu, K. (2010a). Güzel Sanatlar Eğitimi Bölümü Öğrencilerinin Bilimsel Araştırma Yöntemleri Dersine İlişkin Tutumları. Abant İzzet Baysal Üniversitesi Dergisi. 10(2), s.1-8.

Ayaydın, A., \& Kurtuldu, K. (2010b). Sanat Eğitimine Yönelik Tutum Ölçeğinin Geliştirilmesi. Fırat Üniversitesi Sosyal Bilimler Dergisi. 20(2), s.201-209.

Aydınlı, S., \& Akpınar, İ. (2003). Heraclitus \& The Design Studio. ITU Journal, a Architecture, Planning, Design, 5872.

Aytekin, B. A. (2019). Temel Tasarım Kavramlarını Disiplinlerarası Okumak-1, Ankara: Nobel Yayınevi.

Aytekin, C. A. (2008). Resim-iş eğitimi anabilim dalı ögrencilerinin anasanat atölye tercihleri ile temel tasarım dersine yönelik tutum, algı ve beklentileri arasındaki ilişki, Doktora Tezi, Dokuz Eylül Üniversitesi, Eğitim Bilimleri Enstitüsü.

Azizoğlu, N., \& Çetin, G. (2009). 6 ve 7. Sınıf Öğrencilerinin Öğrenme Stilleri, Fen Dersine Yönelik Tutumları ve Motivasyonları Arasındaki İlişki. Kastamonu Eğitim Dergisi. 17(1), s.171-182.

Başbay, M., \& Senemoğlu, N. (2009). Projeye Dayalı Öğretimin Akademik Benlik Kavramı ve Derse Yönelik Tutuma Etkisil. Pamukkale Üniversitesi Eğitim Fakültesi Dergisi, 1(25), 55-66.

Birer, E. (2011). İlk Y1l Mimari Tasarım Stüdyosu Deneyimleri 1. Sınıfta İşler/1. Sınıf İşler, Mimari Tasarım Eğitimi Bütünleşme: 2 Ulusal Sempozyumu, 20-21.10.2011, İstanbul, s.1-14.

Dikmen, M., Tuncer, M., \& Şimşek, M. (2018). Öğrenme Stilleri İle Öğrenmeye Yönelik Tutum Arasındaki İlişki. Uluslararası Sosyal Araştırmalar Dergisi.11(57), s.388-400.
Dural, T. A. (1999). Theatre - Architecture - Education: Theatre As a Pradigm for Introductory Architectural Design Education. Doktora Tezi, Orta Doğu Teknik Üniversitesi Fen Bilimleri Enstitüsü. Ankara.

Eagly, A., \& Chaiken, S. (2007). The Advantages of an Inclusive Definition of Attitude. Social Cognition, 25(5), 582-602.

Emsen, P., Kılı̨̧, D. S., \& Soran, H. (2011). An Examination of The Attitudes of Secondary School Students Towards Research Homeworks According to Different Variants. Procedia Social and Behavioral Sciences. 15(2011), s.25742577.

Esen, E., Elibol, G. C., \& Koca, D. (2018). Basic Design Education and Bauhaus. The Turkish Online Journal of Design, Art and Communication, 8(1), 37-44.

Gökaydın, N. (2010). Temel Sanat Eğitimi. İstanbul: Bireysel ve Toplumsal Yaratıcılık Merkezi.

Hasırcı, Z., \& Coşkun Onan, B. (2020). Anasanat Atölye Seçimleri ve Tutumlar Bağlamında Temel Tasarım Dersini Değerlendirmek. Ondokuz Mayıs Üniversitesi Eğitim Fakültesi Dergisi, 39(2), 101-122.

Özer, B. (2009). Kültür Sanat Mimarlık. İstanbul: Yem Yayınevi.

Özkar, M. (2009). Soyut Düşünme ve Yaparak Öğrenme: Temel Tasarım Eğitiminin Amerika'daki Başlangıçları. A. Artun, \& E. Aliçavuşoğlu içinde, Bauhaus: Modernleşmenin Tasarımı Türkiye'de Mimarlık, Sanat, Tasarım Eğitimi ve Bauhaus (s. 135-151). İstanbul: İletişim Yayınları.

Öztürk, Ö. B. (2007). İmgesel Aritmetik Yöntemiyle Mekan Tasarım ve Bir Tasarım Örneği. Sanatta Yeterlik Tezi, Mimar Sinan Güzel Sanatlar Üniversitesi Fen Bilimleri Enstitüsü. İstanbul.

Ranjan, M. (2005). Lessons from Bauhaus, Ulm and NID: Role of Basic Design in PG Education. DETM Conference at the National Institute of Design, (s. 1-15). Ahmedabad.

Sakallı Uğurlu, N. (2018). Sosyal Psikolojide Tutumlar ve Tutum Değişimi. Ankara: İmge Kitabevi.

Seylan, A. (2005). Temel Tasarım. İstanbul: İletişim Yayınevi.

Taşkesen, S. (2019). Sanat Eğitimi Alan Öğrencilerin Temel Tasarım Dersine Yönelik Tutum ve Motivasyonları ile Akademik Başarı Arasındaki İlişki Üzerine Bir Araştırma. EJER Congress (s. 1196-1197). Ankara: Anı Yayınc1lık.

Tülüce, E. A. (2016). Proje Tabanlı Öğrenme Yönteminin Görsel Sanatlar Öğretmeni Adaylarının Akademik Başarı ve Tutumlarına Etkisi. Yüksek Lisans Tezi, Atatürk Üniversitesi Eğitim Bilimleri Enstitüsü. Erzurum.

Uysal, E. (2015). Temel Tasarım Dersine İlişsin Öğrenci Görüşleri. edi: Sanat, Tasarım ve Bilim Dergisi, 1(14), 5165.

Yıldırım, İ. (2018). İç Mimarlık Bölümlerindeki Temel Tasarım Eğitiminin Teorik ve Pratik Yönden İçerik Analizi. Yüksek Lisans Tezi, Hacettepe Üniversitesi Güzel Sanatlar Enstitüsü. Ankara. 